\title{
Peningkatan Kapasitas Meliponikultur dengan Pengayaan Pakan Lebah Madu di Kelurahan Kahu Kecamatan Bontocani Kabupaten Bone
}

\author{
Sitti Nuraeni*, Budiaman, Andi Sadapotto, Baharuddin, Marwan Rajab dan Andi Prastiyo \\ Fakultas Kehutanan Universitas Hasanuddin. Jl. P. Kemerdekaan Km. 10 Tamalanrea, Makassar 90245
}

Article history

Received: 18-10-2021

Revised: 04-11-2021

Accepted: 04-11-2021

*Corresponding Author:

Sitti Nuraeni,

Fakultas Kehutanan

Universitas Hasanuddin. Jl.

P. Kemerdekaan Km. 10

Tamalanrea, Makassar

90245, Indonesia;

Email:

nuraenisitti@gmail.com

\begin{abstract}
The purpose of this community service program is to provide knowledge about the importance of forests, woody forage plants and enrichment of feed types around meliponiculture farmer groups. The methods used in this activity as part of the mentoring are pre-tests, lectures, video screenings, discussions about knowledge of forest bee hunting, trigona beekeeping and the importance of forests and bee feed. The next activity was the distribution of flowering tree seedlings and visits to the meliponiculture location for farmer groups. The result of this community service activity is that the community in Kahu Village can develop knowledge about the material presented by seeing the enthusiasm and appreciation of the participants or members of the farmer groups who participated in the many questions during the discussion. Receipt of plant and tree seeds that are distributed immediately to the plant and group reception during visits to their meliponiculture area. Awareness of planting various types of vegetation and maintaining forests is an important factor for the stability of colony strength and can even increase the beekeeping productivity of all types of bees in Kahu Village, Bontocani District and its surroundings. Assistance from various parties is needed in order to increase the productivity of honey bee cultivation in Kahu Village, Bontocani District.
\end{abstract}

Keywords: forest; sustainability, feed; enrichment; meliponiculture

Abtrak: Tujuan dari program pengabdian kepada masyarakat ini adalah untuk memberikan pengetahuan tentang arti penting hutan, jenis tumbuhan pakan yang berkayu dan pengayaan jenis-jenis pakan di sekitar meliponikultur kelompok tani. Metode yang digunakan dalam kegiatan ini sebagai bagian dari pendampingan adalah pre-tes, ceramah, pemutaran video, diskusi tentang pengetahuan perburuan lebah hutan, peternakan lebah trigona dan arti penting hutan serta pakan lebah. Kegiatan selanjutnya pembagian bibit pohon berbunga dan kunjungan ke lokasi peternakan lebah trigona kelompok tani. Hasil dari kegiatan pengabdian kepada masyarakat ini adalah masyarakat di Kelurahan Kahu dapat mengembangkan pengetahuan tentang materi yang disampaikan dengan melihat antusias dan apresiasi peserta atau anggota kelompok tani yang ikut dari banyaknya pertanyaan saat diskusi berlangsung. Penerimaan bibit tanaman dan pohon yang dibagikan segera ditanan dan penerimaan kelompok saat kunjungan ke area meliponikultur mereka. Kesadaran menanam berbagai jenis vegetasi dan memelihara hutan merupakan faktor penting untuk kestabilan kekuatan koloni dan bahkan dapat meningkatkan produktivitas perlebahan semua jenis lebah yang ada di Kelurahan Kahu Kecamatan Bontocani dan sekitarnya. Pendampingan dari berbagai pihak sangat diperlukan dalam rangka meningkatkan produktivitas usaha budidaya lebah madu di Kelurahan Kahu Kecamatan Bontocani.

Kata Kunci: kelestarian; hutan, pengayaan; pakan; meliponikultur 


\section{PENDAHULUAN}

Lebah Apis dorsata binghami merupakan lebah hutan besar dan endemik Pulau Sulawesi. Sedangkan lebah Wallacetrigona incisa dan Tetragonula biroi juga merupakan lebah tanpa sengat (stingless bee) yang telah banyak dibudidayakan masyarakat Sulawesi. Lebah hutan menjadi sumber madu yang hanya dapat diburu jika ingin mendapatkan madunya. Lebah tanpa sengat dipelihara/budidayakan secara tradisional oleh masyarakat pedesaan sekitar kawasan hutan yang lebih populer disebut "lebah trigona". Koloni trigona dapat diambil langsung dari alam dengan cara menebang pohon dan memotong bagian batang yang ada sarang lebahnya. Batang yang berisi koloni trigona ini disebut glodokan kemudian dibawa pulang untuk dipindahkan ke kotak baru atau stup budidaya. Peternakan lebah tanpa sengat dikenal sebagai meliponikultur (Rosales, 2013). Madu trigona merupakan madu yang paling istimewa diantara banyak madu-madu lainnya. Demikian warga Kelurahan Kahu banyak yang melakukan perburuan lebah hutan dan juga telah melakukan budidaya lebah ternak trigona untuk meningkatkan pendapatan keluarga.

Usaha perburuan lebah hutan di Kelurahan Kahu merupakan usaha yang turun temurun yang dilakukan oleh kelompok pemburu lebah hutan. Perburuan lebah hutan bagi warga kelurahan Kahu hanya bersifat musiman. Sedangkan usaha budidaya lebah tanpa sengat sudah mulai berkembang pesat karena panen madu tidak tergantung pada musim. Peternak yang telah berhasil membelah koloni dan memindahkan ke dalam kotak-kotak yang lebih mudah dipanen. Peternak yang berhasil memiliki ratusan koloni menjadi inspirasi bagi warga lain yang tertarik ikut membudidayakan.

Permintaan akan madu semakin meningkat (Fatma et al., 2017) apalagi selama masa pandemi Covid-19 karena telah dibuktikan penelitian madu sebagai antimikrobial dan meningkatkan kekebalan tubuh (Saikat et al., 2020). Demikian pula halnya permintaan produk madu dari Kelurahan Kahu juga meningkat dengan banyaknya pengiriman keluar Pulau Sulawesi. Meningkatnya permintaan tentu akan menjadi penggerak bagi warga lain untuk semangat membudidayakan lebah trigona.

Sumber pakan lebah madu adalah semua jenis tanaman berbunga bisa berupa tanaman hutan, tanaman pertanian, perkebunan, hortikultura dan tumbuhan liar yang mengandung nektar sebagai bahan madu, polen dan propolis juga dapat digunakan sebagai pakan lebah (Sarwono, 2001). Trigona menghasilkan madu dengan mengkonsumsi nektar dari bunga, dan memproduksi propolis dari mengkonsumsi getah serta memproduksi bee pollen dari serbuk sari bunga (Riendriasari dan Krisnawati, 2017). Lebah sangat membutuhkan lingkungan yang kaya akan sumber pakan maupun material sarang (Harjanto et al., 2020).

Pemburu lebah hutan dan peternak lebah madu trigona sebagai mitra telah terjalin kerjasama dengan baik sejak tujuh tahun terakhir. Kerjasama baik melalui berbagai skim pendanaan berupa penelitian, pembinaan, pendampingan dan penempatan Kelurahan Kahu sebagai lokasi KKN (Kuliah Kerja Nyata) tematik lebah madu. Mitra peternak lebah trigona yang telah fokus menekuni budidaya telah membentuk kelompok. Namun bagi yang pemula masih belajar budidaya lebah trigona sebagian masih mandiri. Kelompok yang telah terbentuk yaitu kelompok peternak KahuToa dan Kelompok Sejahtera.

Keberlanjutan perburuan lebah hutan dan budidaya lebah trigona dapat terjamin jika kondisi hutan tetap dapat dipertahankan. Oleh karena itu kelestarian sumber pakan dari beragam jenis tumbuhan baik yang ada di hutan dan sekitarnya harus tetap terjaga. Bahkan peningkatan kapasitas perlebahan di Kelurahan Kahu dapat terus dikembangkan lebih luas di sekitar Kecamatan Bontocani. Salah satu upaya yang dapat dilakukan adalah dengan pengayaan pakan alam sebagai sumber nektar dan polen. Penanaman berbagai jenis vegetasi yang berbunga sepanjang tahun merupakan faktor penting untuk kestabilan kekuatan koloni dan bahkan dapat meningkatkan produktivitas perlebahan semua jenis yang ada di Kecamatan Bontocani dan sekitarnya. Demikian 
pula dengan upaya menanamkan kesadaran untuk tetap menjaga kelestarian hutan adalah hal penting bagi warga Kelurahan Kahu.

\section{METODE}

Kegiatan pengabdian masyarakat ini dilakukan dalam bentuk kegiatan penyuluhan dan menjadi bagian dari pendampingan pembinaan yang berkelanjutan dari beberapa skim pengabdian dan penelitian di Kelurahan Kahu. Mitra utama dalam kegiatan pengabdian kepada masyarakat ini adalah peternak lebah trigona. Peternak lebah sebagian besar berusia produktif (15-65 thn) 96,7\%. Beternak lebah umumnya adalah pekerjaan sampingan dan sebagian besar berjenis kelamin laki-laki. Tingkat pendidikan peternak lebih banyak hanya tamat sekolah tingkat lanjutan atas (SMA) sebanyak 30\%, lulusan SMP sebanyak 43,3\%, lulusan SD sebanyak 13,3\% dan lulusan perguruan tinggi sebanyak $13,3 \%$.

Adapun metode pelaksanaan pengabdian kepada masyarakat dilakukan dalam bentuk caramah langsung dengan beberapa tahap sebagai berikut:

1. Menggali pengetahuan dan potensi awal dari mitra melalui pre-tes tentang perburuan lebah hutan, peternakan lebah trigona dan pengetahuan tentang arti penting hutan dan pakan lebah.

2. Ceramah tentang kesadaran pentingnya kelestarian hutan

Kegiatan pengabdian kepada masyarakat dilaksanakan dengan metode ceramah dengan materi pertama adalah arti penting dari produk khas, yaitu produk madu dll dari Kecamatan Bontocani. Dilanjutkan diskusi untuk mengetahui potensi dan masalah yang dihadapi oleh kelompok tani.

Materi kedua adalah peranan penting hutan kehidupan dan hubungannya dengan lebah madu serta keberlanjutan usaha perburuan dan ternak lebah madu di Kelurahan Kahu.

3. Pemutaran video melipolikultur yang berhasil dengan mengintegrasikan ekowisata berbasis lebah trigona.

4. Pelaksanaan pengabdian kepada masyarat di Kelurahan Kahu dilanjutkan dengan pembagian bibit pohon berkayu dan pohon berbunga sebagai pakan lebah madu.

5. Kegiatan diakhiri dengan kunjungan ke lokasi peternakan lebah trigona (meliponikultur) kelompok dan diskusi langsung tentang budidaya dan sumber pakan yang ada.

\section{HASIL DAN PEMBAHASAN}

Pelaksanaan kegiatan pengabdian kepada masyarakat kelompok pemburu dan/atau peternak lebah trigona dilakukan di Kelurahan Kahu Kecamatan Bontocani Kabupaten Bone. Wilayah Kelurahan Kahu, Kecamatan Bontocani yang termasuk daerah tangkapan hujan DAS Bila Walanae. Kelurahan Kahu ini terletak pada jarak kurang lebih $5 \mathrm{~km}$ dari ibukota Kecamatan Bontocani dan $48 \mathrm{~km}$ dari ibukota Kabupaten Bone, dengan luas wilayah kelurahan 1.544 ha (Gambar 1). Dari luas lahan tersebut terdapat areal persawahan seluas 297 ha, padang rumput seluas 115 ha, hutan rakyat 30 ha, dan lahan kritis seluas 240 ha. Jumlah penduduk Kelurahan Kahu sebanyak 1.710 jiwa dengan jumlah kepala keluarga $421 \mathrm{KK}$. Tingkat perekonomian di Kelurahan Kahu berbasis agraris persawahan dengan luas lahan rata-rata penduduk $\pm 0,4 \mathrm{ha} / \mathrm{KK}$. 

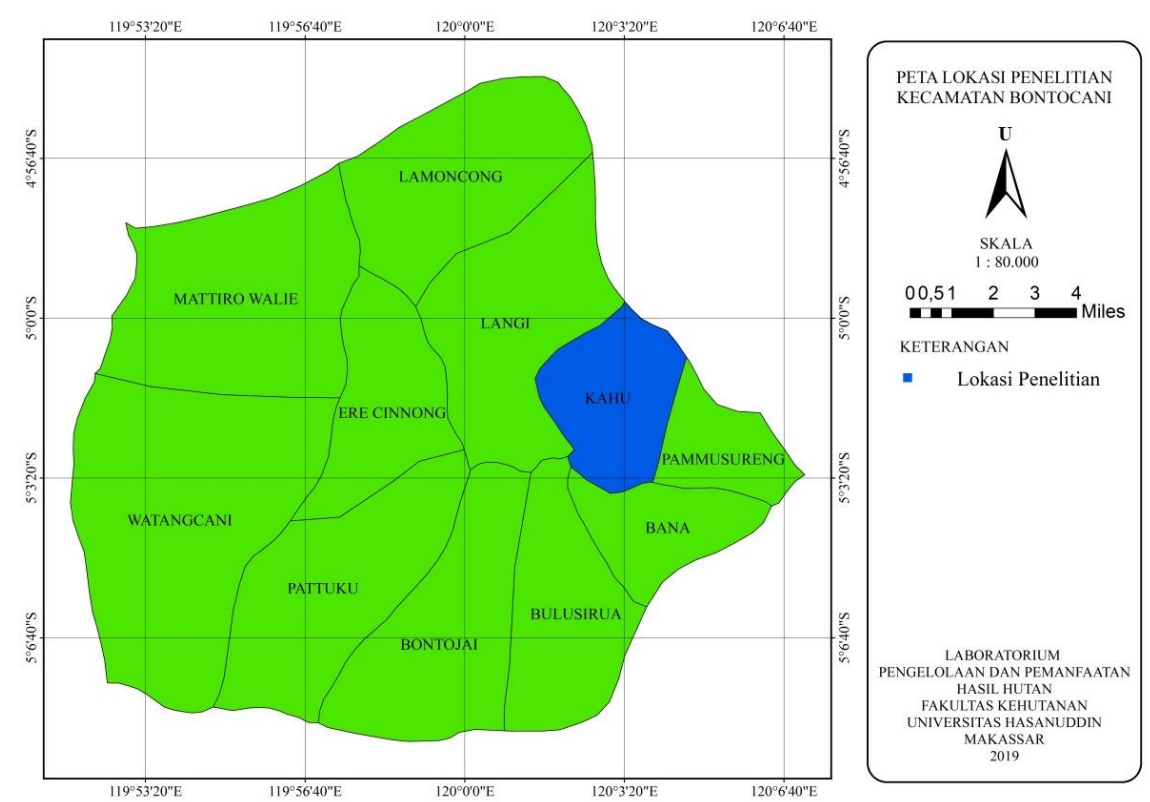

Gambar 1. Peta letak Kelurahan Kahu, Kecamatan Bontocani, Kabupaten Bone

Pelaksanaan pre-tes untuk menggali pengetahuan anggota kelompok tentang arti penting hutan sebagai habitat dan penyediaan pakan lebah. Pengalaman berburu lebah atau beternak lebah, jumlah koloni dan informasi lainnya juga menjadi bagian dari beberapa pertanyaan yang disediakan dalam pretes (Gambar 2).

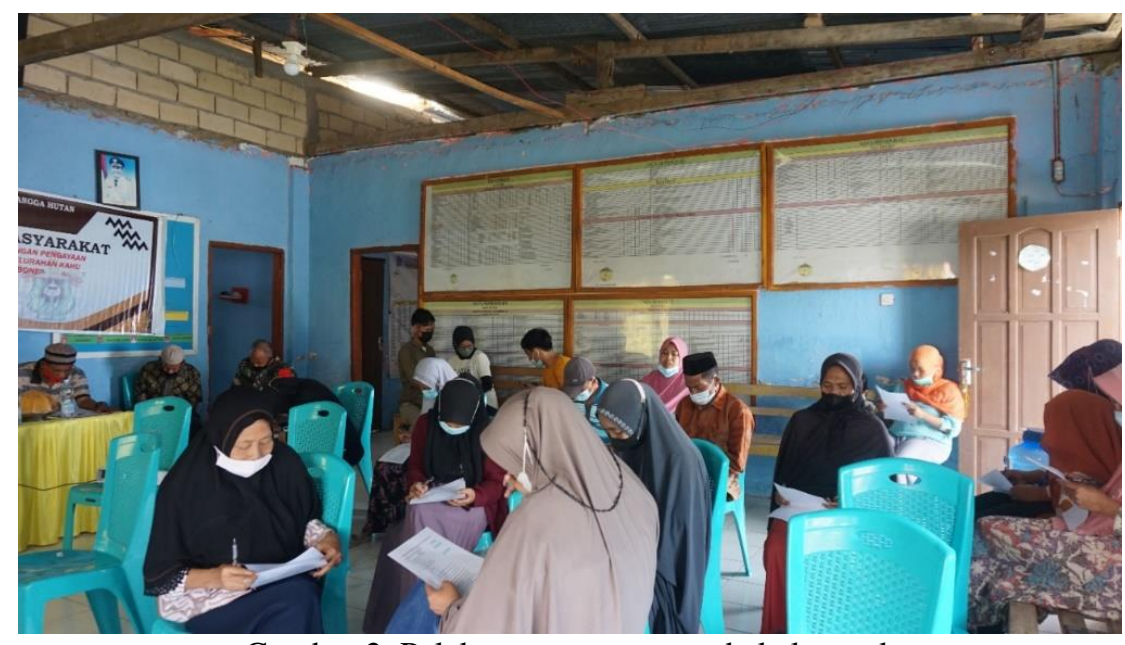

Gambar 2. Pelaksanaan pre-tes pada kelompok

Hasil pre-tes menunjukkan semua anggota paham peranan tanaman berbunga adalah pakan utama (nektar dan polen) lebah namun belum semua paham bahwa juga sebagai sumber ektra flora berupa embun madu dan resin bahan propolis dari berbagai tanaman dan pohon berkayu. Anggota kelompok yang sudah menjalankan usaha ternak lebah lebih dari 2 tahun dengan jumlah koloni lebih dari 10 koloni. Anggota kelompok menempatkan koloninya di sekitar rumah tinggal atau di dalam kebun sekitar hutan. Harjanto et al. (2020), posisikan stup dekat dengan sumber pakan karena semakin dekat dengan sumber pakan, waktu jelajah lebah dalam mengumpulkan pakan berupa nektar dan serbuk sari menjadi lebih cepat. Begitu juga energi yang dibutuhkan untuk hilir mudik mengunjungi bunga-bunga sumber pakan jadi lebih efisien.

Kegiatan selanjutnya adalah penyajian materi pengabdian kepada masyarakat. "Sumber pakan dan kondisi habitat sesuai untuk pemeliharaan lebah madu bisa yang dimanfaatkan sebesar besarnya 
merupakan syarat pemeliharaan lebah dilaksanakan pemeliharaan lebah madu yang baik. Kelimpahan sumber pakan yang tinggi akan meningkatkan produksi madu dan propolis lebah. Lebah madu akan berkembang biak dan mempunyai koloni yang besar/individu yang banyak jika kondisi lingkungan tempat tinggal sangat mendukung. Lingkungan yang dibutuhkan adalah tersedianya banyak tanaman berbunga penghasil nektar dan pollen serta cukup cadangan makanan lainnya. Simpanan nektar yang banyak disarang akan merangsang pertumbuhan koloni lebah yang baik, yaitu dalam membuat sarang baru dan juga dalam memproduksi telur. Sedangkan ketersediaan pollen di sarang yang cukup akan memberikan kualitas generasi lebah yang baik, kuat dan lama hidup yang relatif panjang." merupakan petikan materi ceramah (Gambar 3 dan 4). Sedangkan "studi banding secara singkat" melalui virtual tentang keberhasilan budidaya lebah trigona serta integrasi dengan ekowisata berbasis lebah dilakukan saat pemutaran video (Gambar 5). Antusias dan apresiasi menyimak ceramah dan video dinyatakan saat pemaparan, masalah, tantangan dan harapan yang akan datang dalam hal budidaya lebah trigona sesuai pengalaman anggota kelompok (Gambar 6). Dewantari dan Suranjaya (2019), penyampaian materi dan pelatihan lebah madu trigona sangat penting dilakukan agar kelompok tetap dapat melakukan aktivitasnya dan juga untuk menunjang keberlanjutan peternakannya.

Kegiatan terakhir dari pertemuan anggota kelompok pembagian bibit tanaman hutan untuk pakan dan penghasil kayu (Gambar 7). Jenis bibit untuk pengayaan pakan adalah pohon kaliandra (Calliandra sp). Produktivitas lebah trigona sangat ditentukan oleh ketersediaan pakan (Setiawan et al., 2021) dan pakan merupakan kebutuhan untuk keberlanjutan peternakan lebah trigona (Erwan et al., 2020). Jenis tanaman hutan yang lain yang dibagikan kepada peternak lebah adalah jenis kayu afrika (Maesopsis eminii Engl.) untuk bahan pembuatan rumah lebah ataupun kotak lebah. Jenis kayu untuk bahan rumah lebah dan kotak atau stup lebah tidak ada jenis yang khusus. Jenis kayu yang digunakan untuk pembuatan kotak lebah madu Trigona sp kelompok tani lebah madu pendua, Desa Pendua, Kec. Kayangan, Kab. Lombok utara adalah kayu dadap (Erythrina vareigata L) (Wahyuningsih et al., 2020). Pada umumnya masyarakat peternak lebah madu trigona di Kelurahan Kahu mengenal budidaya lebah ini melalui pengamatan keberhasilan beberapa orang sebagai perintis. Awalnya peternak membudidayakan dengan menggunakan gelodok yang diambil dari pohon seperti pohon jati putih (Gmelina arborea), pohon mangga (Mangifera indica) dan beberapa jenis pohon lainnya (Gambar 8). Dari gelodok barulah dipindahkan ke dalam stup. Di Kelurahan Kahu ini masih membutuhkan mengenai teknik dan metode dalam budidaya lebah madu trigona terutama pengenalan kotak lebah yang produktif dan efiesin.

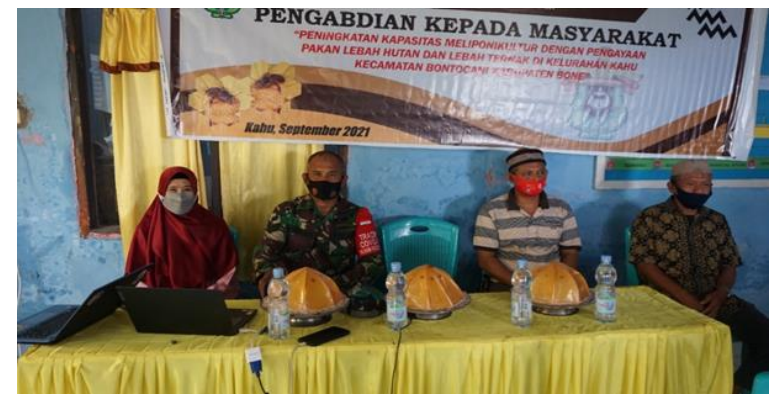

Gambar 3. Pelaksanaan pengabdian kepada masyarakat di Kelurahan Kahu.

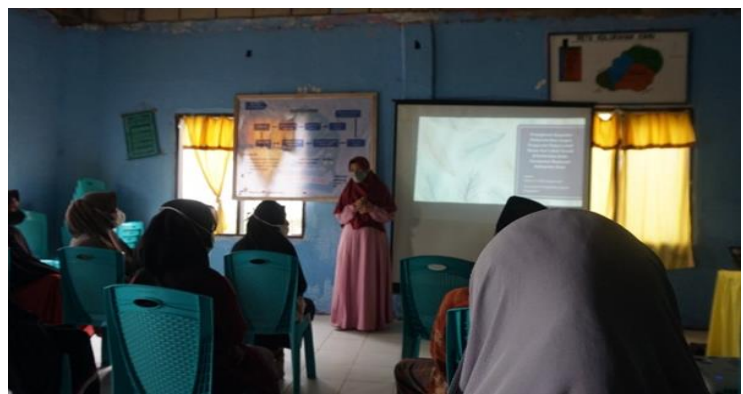

Gambar 4. Pelaksanaan penyuluhan/ceramah tentang arti penting hutan bagi kehidupan lebah hutan, keberlanjutan usaha ternak lebah trigona dan pakannya 


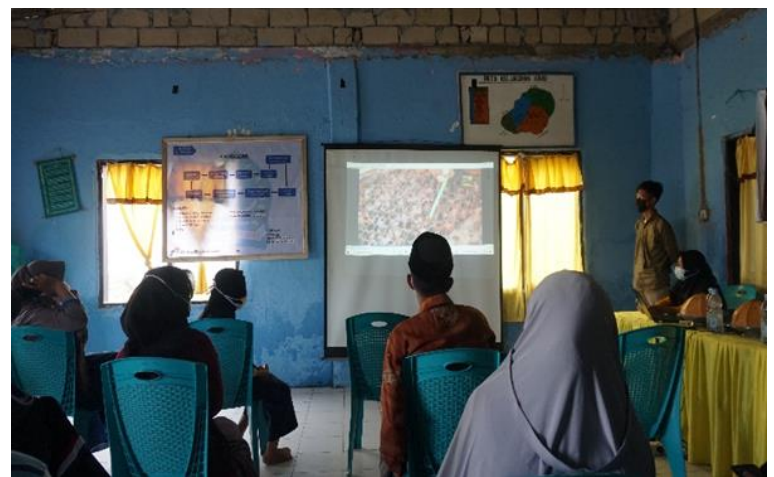

Gambar 5. Pemutaran video usaha ternak lebah trigona yang terintegrasi dengan ekowisata

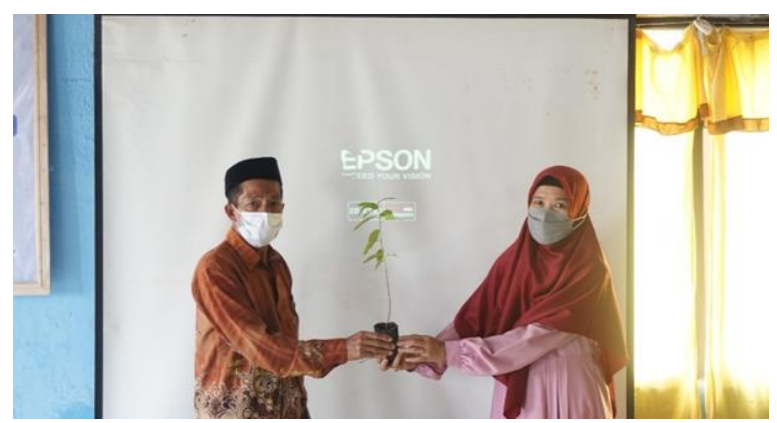

Gambar 7. Pembagian bibit pakan lebah madu dan pohon berkayu

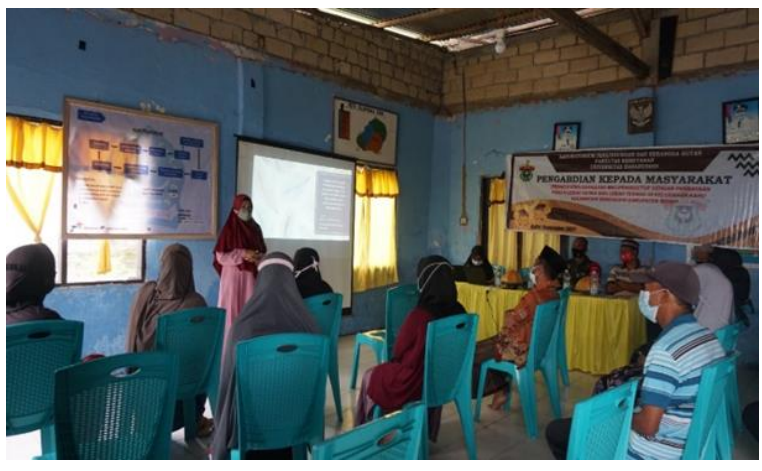

Gambar 6. Diskusi tentang arti penting hutan bagi kehidupan lebah hutan, keberlanjutan usaha ternak lebah trigona dan pakannya

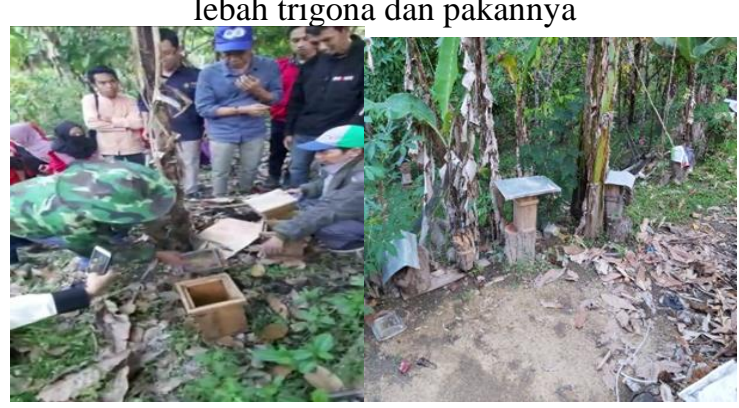

Gambar 8. Kunjungan ke area peternakan lebah trigona warga Kelurahan Kahu

\section{KESIMPULAN DAN SARAN}

Kesimpulan yang dapat kami peroleh dari kegiatan pengabdian di Kelurahan Kahu Kecamatan Bontocani adalah peningkatan pengetahuan terkait pentingnya hutan dan jenis-jenis vegetasi bagi keberlangsungan budidaya lebah madu trigona. Peternak memiliki semangat dan respon yang tinggi terhadap kegiatan pengabdian ini dan mereka sangat mengharapkan pendampingan serta pembimbingan dilakukan secara kontinyu. Warga Kelurahan Kahu antusias untuk menanam berbagai jenis tanaman sumber nektar dan polen serta jenis pohon penghasil kayu lainnya. Kegiatan pengabdian selanjutnya agar ada komitmen instansi terkait untuk membantu mengintergrasikan menjaga kelestarian hutan dengan meningkatkan nilai jual jasa lingkungan seperti wisata alam berbasis lebah madu di Kelurahan Kahu.

\section{Ucapan Terima Kasih}

Ucapan terima kasih kepada Universitas Hasanuddin dalam hal ini Fakultas Kehutanan yang telah mendanai kegiatan pengabdian pada masyarakat. Ucapan terima kasih juga kami haturkan kepada Bapak Lurah Kelurahan Kahu, Kelompok Peternak Lebah Trigona dan warga Kelurahan Kahu Kecamatan Bontocani atas dukungan dan kerjasamanya sehingga kegiatan ini terlaksana. 


\section{DAFTAR PUSTAKA}

Erwan, D. K. Purnamasari, W. Agustin. 2020. Pengaruh Desain Kotak Terhadap Produktivitas Lebah Trigona sp. Jurnal Sains Teknologi \& Lingkungan, 6 (2): 192-201. DOI https://doi.org/10.29303/jstl.v6i2.206.

Fatma, I., S Haryanti, S W A Suedy. 2017. Uji Kualitas Madu Pada Beberapa Wilayah Budidaya Lebah Madu Di Kabupaten Pati. Jurnal Biologi, 6 (2): 58-65.

Dewantari, M dan I.G. Suranjaya. 2019. Pengembangan Budidaya Lebah Madu Trigona Spp Ramah Lingkungan Di Desa Antapan Kecamatan Baturiti Kabupaten Tabanan. Buletin Udayana Mengabdi, 18 (1): 114-119.

Harjanto, S., M. Mujianto, A.A. Ramlan. 2020. Budidaya Lebah Madu Kelulut Sebagai Alternatif Mata Pencaharian Masyarakat. Tropenbos Indonesia dan Swaraowa, 28p.

Rosales, G. R. O. 2013. Medicinal uses of Melipona beecheii honey, by the ancient Maya. In P. Vit et al. (Eds.), Pot-honey a legacy of stingless bees (pp. 229-240). New York: Springer.

Sarwono, B. 2001. Kiat Mengatasi Masalah Praktis Lebah Madu. Jakarta: AgroMedia Pustaka.

Saikat, A.S.M., S Mahmud, Md. R Hossain, Md. A S Imran, R Islam, MS Alam, M H Masud, Md. Z Abedin, and Md. E Uddin. 2020. Anticipation of natural honey in fighting against novel coronavirus: pharmacologic and therapeutical study. Journal of Natural Remedies, 21(8): (1), 142-146.

Setiawan, A., T Susdiyanti, K.B. Meiganati. 2021. Produktifitas lebah Trigona sp. pada berbagai teknik budidaya di Desa Nayagati Kecamatan Leuwidamar Kabupaten Lebak. Jurnal Nusa Sylva, 21(1): 26-31

Riendriasari, S.D., Krisnawati. 2017. Produksi propolis mentah (raw propolis) lebah madu Trigona spp di Pulau Lombok. Ulin J Hut Trop, 1(1): 71-75.

Wahyuningsih, E., F. T Wulandari, A. T. Lestari. 2020. Peningkatan produktivitas lebah madu Trigona sp dengan kayu dadap (Erythrina vareigata 1) sebagai bahan baku stup lebah, Di Desa Pendua, Kec. Kayangan, Kab. Lombok Utara, NTB. Jurnal Pendidikan dan Pengabdian Masyarakat, 3 (4): 274-278. 